\title{
Huumeita suonensisäisesti käyttävien terveysneuvontapisteen asiakkaiden muutosvalmius ja siihen vaikuttavat tekijät
}

Tutkimuksessa tarkastellaan suonensisäisesti huumeita käyttävien muutosvalmiutta ja siihen liittyviä tekijöitä. Muutosvalmiudella tarkoitetaan itse ilmaistua halua ja valmiutta muuttaa huumeidenkäyttöä, toimia muutokseen eteen ja ottaa vastaan ammattiapua. Aineisto $(\mathrm{N}=99)$ on kerätty Kuopiossa sijaitsevassa huumeita suonensisäisesti käyttäville tarkoitetussa Terveysneuvontapiste Portissa. Muutosvalmiutta arvioitïn tätä tutkimusten varten laaditulla mittarilla, joka perustuu muutosmotivaatiota mittaavan DUDIT-E-mittarin muutosvalmiuden itsearviointiosioon. Tutkimuksessa tarkastellaan myös vastaajien elämäntyytyväisyyttä, jota arvioitiin tutkimusta varten muodostetulla elämäntyytyväisyyden summamuuttujalla. Tutkimuksessa verrattiin matalan ja korkean muutosvalmiuden ryhmiä. Tutkimukseen osallistuneiden terveysneuvontapiste Portin asiakkaiden muutosvalmius on korkealla tasolla ja suurin osa vastaajista toivoi huumeiden käyttöönsä muutosta. Muutosvalmiutta ennustivat huumeiden käytön koettu haitallisuus, myönteinen suhtautuminen ammattiapuun sekä työssä käyminen, työkokeilu tai opiskelu. Uskonnollisten yhteisöjen toimintaan osallistuminen oli myös yhteydessä korkeampaan muutosvalmiuteen. Jos potilaan muutosvalmius ja muutosta edistävät tekijät ja niiden merkitys pystyttäisiin tunnistamaan paremmin, Portin tavoin toimivat matalan kynnyksen pisteet voisivat kohdentaa tarkemmin yksilöityä neuvontaa ja ohjausta huumeita suonensisäisesti käyttäville henkilöille.

Avainsanat: muutosvalmius, DUDIT-E, terveysneuvontapiste Portti, suonensisäinen huumeiden käyttö, elämäntyytyväisyys

\section{PÄLVI HAVUKAINEN, ANNA-MARI PASANEN, KIRSI HONKALAMPI, PIRJO SAARINEN, JUHO SAARI}

\section{JOHDANTO}

Muutosvalmiudella tarkoitetaan koettua ja itse ilmoitettua tarvetta, valmiutta tai halua tehdä muutoksia huumeiden käytössä, toimia muutoksen eteen ja ottaa vastaan päihdehoitoa (1). Muutosvalmius on osa laajempaa muutosmotivaation käsitettä (2). Muutosmotivaatiota on tutkittu erityisesti päihdehoidon kontekstissa ja sitä pidetään hoitoon hakeutumisen ja lopputuloksen sekä hoidon suunnittelun ja toteuttamisen kannalta oleellisena tekijänä (3). Hoitokontekstin ulkopuolella tehdyt tutkimukset ja hoitoon hakeutuneita ja hakeutumattomia vertailevat tutkimukset kertovat osaltaan muutosvalmiuden kehittymiseen vaikuttavista tekijöistä sekä päihdehoitoon hakeutumattomien muutoksen kaipuusta. Tässä tutkimuksessa tarkastellaan terveysneuvontapisteen asiakkaiden muutosvalmiutta.

Tutkimuksen teoreettisena lähtökohtana on muutosmotivaation kognitiivinen teoria. Kogni- 
tiivisten mallien yhteinen lähtökohta on, että henkilön subjektiivinen arviointi huumeiden käytön haitoista ja hyödyistä, odotuksista ja henkilökohtaisista painoarvoista ovat keskeisessä asemassa huumeiden käyttämisessä ja muutosmotivaation viriämisessä. Malleissa korostuu ajatus ihmisestä rationaalisena toimijana (4). Tunnettu kognitiivinen teoria on transteoreettinen muutosmalli (TTM), joka on kehitetty riippuvuusongelmista selviytymiseen liittyvien muutosprosessien tarkastelua varten (5). Malli koostuu viidestä eri muutosvaiheesta. Esiharkintavaiheessa ihmiset eivät vielä näe tarvetta muutokselle. Huolestuminen ja haavoittuvuuden tajuaminen voivat johtaa harkintavaiheeseen, jossa ongelmaa pohditaan vakavasti ja vertaillaan erityisesti muutokseen liittyviä etuja ja haittoja. Valmisteluvaiheessa muutoksen kannalle on päädytty ja alustavasti sitouduttu. Toimintavaiheessa toteutetaan muutosta edellyttämät käytännön ratkaisut. Jos tähän pystytään, siirrytään ylläpito-vaiheeseen, jossa muutostulokset integroituvat osaksi elämää (5). Eteneminen vaiheesta toiseen voi olla spiraalimaista tai sirkulaarista. Ennen vakaaseen muutokseen päätymistä voi tulla retkahduksia ja vaiheet käydään läpi useita kertoja (2).

Muutosvalmius on muutosmotivaation kanssa limittyvä käsite ja muutosmotivaation ja muutosvalmiuden kehittyminen mielletään toisiinsa kytkeytyviksi. Millerin teoriassa (2) motivaatioon kuuluvat ihmisen valmius, halukkuus ja kykenevyys muuttua. Kyvyllä muutokseen tarkoitetaan ihmisen tarpeellisia taitoja, voimavaroja ja luottamusta, joita muutoksessa tarvitaan. Halulla muutokseen tarkoitetaan sitä, miten tärkeänä ihminen pitää muutosta. Valmiudella tarkoitetaan ihmisen lopullista päätöstä muuttua (2). Muutosvalmius-käsitettä käytetään eri tavoin huumeidenkäyttäjien hoitovalmiutta kuvaavissa kognitiivisissa malleissa (6). TCU-mallissa (7) valmius on ongelmien tunnistamista ja avun kaipaamista seuraava hoitovalmiuden kolmas ja viimeinen taso, jossa ihminen on valmis ja sitoutunut päihdehoitoon (6). CMRS-mallissa (8) hoitovalmius koostuu eri osatekijöistä, joista valmius eli havaittu tarve hakea apua riippuvuuskäyttäytymisen muuttamiseen on yksi faktori ulkoisten olosuhteiden, motivaation ja tarjolla olevan hoidon sopivuuden ohella (6). Tässä tutkimuksessa muutosvalmiudella tarkoi- tetaan koettua ja itse ilmoitettua valmiutta, toivetta tai halua tehdä muutoksia huumeiden käytössä, toimia muutoksen eteen ja ottaa vastaan muutosta tukevaa hoitoa. Käsite perustuu näitä malleja integroivaan huumeiden käyttöä ja hoitovalmiutta kartoittavaan DUDIT-E (Drug Use Disorders Identification Test Extended) -mittariin (1). Muutosvalmius tässä yhteydessä sisältää ongelmien tunnistamiseen liittyvää halua tai kaipausta muutokseen, mutta se ei kuitenkaan kartoita motivaatiota kokonaisuudessaan. Muutosvalmius tutkimuksessa perustuu huumeidenkäyttäjän omaan ilmoitukseen.

Aikaisemman tutkimuksen perusteella päihdehoidon ulkopuolella olevien kovien huumeiden käyttäjien muutosvalmius on ollut yhteydessä huumeiden käyttöön liittyvien haittojen tunnistamiseen (4, 6, 9-13); ongelmalliseen huumeiden käyttöön $(9-10,13)$ ja masentuneisuusoireisiin (9-11, 14-16). Aikaisempi hoitohistoria on ollut yhteydessä korkeampaan muutosvalmiuteen (11) ja hoitoon hakeutumiseen (17), mutta myös matalampaan muutosvalmiuteen (10). Myös hoitoa koskevat käsitykset ja asenteet vaikuttavat osaltaan muutosvalmiuteen. Alkoholiriippuvaiset, jotka kokivat avun ja hoidon pyytämisen ja saamisen positiivisena, olivat valmiimpia muutokseen kuin hoitoon kielteisesti suhtautuvat (18).

Vaikka valtaosa päihdehuollon huumeasiakkaista oli esim. vuonna 2013 nuoria, 20-25-vuotiaita miehiä (19) on sosiodemografisten tekijöiden yhteydestä muutosvalmiuteen on saatu vaihtelevia tuloksia. Rappin ym. (9) muutosvalmiutta koskevassa tutkimuksessa, johon osallistui 446 huumeriippuvaista henkilöä, ikä ja sukupuoli vaikuttivat vain vähän muutosvalmiuteen. "Maturing out" -hypoteesin (20) mukaan huumeiden käyttö voi menettää vetovoimaisuutensa iän karttumisen myötä joko luonnollisen elämänkulun kehityksen myötä tai koska huumeuran kestäessä pidempään käyttäjä väsyy mahdollisesti raskaaseen ja vaaralliseen elämäntilanteeseensa (6). Korkeampi ikä on ollut yhteydessä suurempaan muutosvalmiuteen joissakin tutkimuksissa $(6,21)$.

Huumeita suonensisäisesti käyttävien elämäntyytyväisyyttä on tutkittu jonkin verran viime vuosina (22-24). Elämäntyytyväisyydellä tarkoitetaan subjektiivisen hyvinvoinnin kognitiivista puolta: ihmisen omaa arviota omasta elämästään. Elämäntyytyväisyys on suppeampi käsite 
kuin elämänlaatu (25). Oletuksen mukaan huumeiden käyttäminen heikentää elämänlaatua ja lisää tyytymättömyyttä elämään, mikä toimii työntävänä tekijänä kohti muutosta aktiivisen huumeiden käytön vaiheessa. Toisaalta elämäänsä tyytyväisellä voi olla enemmän voimavaroja muutoksen toteuttamiseen. (23). Huumeita suonensisäisesti käyttävien elämäntyytyväisyys on matalampaa kuin väestössä keskimäärin (2225). Päihdehoidon aikana elämäntyytyväisyys nousee lyhyellä ja pitkällä aikavälillä (22-23) ja korkeampi elämäntyytyväisyys on yhteydessä parempaan toipumiseen (22).

Tutkimus on osa Kuopion kaupungin ja Itä-Suomen yliopiston tutkimusprojektia, jossa selvitetään huumeita suonensisäisesti käyttäville tarkoitettujen terveysneuvontapisteiden asiakkaiden hyvinvointia, tulonsiirtojen ja palvelujen käyttöä ja muutosvalmiutta (26). Terveysneuvontapisteet ovat matalan kynnyksen palveluja, joissa huumeiden käyttäjät voivat anonyymisti saada erilaisia terveyspalveluja. Terveysneuvontapisteiden toimintaan kuuluu terveysneuvonnan tarjoaminen ja asiakkaiden tukeminen omasta hyvinvoinnista huolehtimiseen, käytettyjen pistosvälineiden vaihtaminen puhtaisiin, ilmaisten A- ja B-hepatiittirokotteiden antaminen, HIV- ja hepatiittitestien ottaminen sekä haavojen ja lievien ihotulehdusten hoitaminen. Terveysneuvontapisteissä saa myös ohjausta ja tukea muihin hoitopaikkoihin hakeutumiseen tai asioiden hoitamiseen (27). Terveysneuvontapistetoiminta kuuluu ehkäisevään päihdetyöhön. Tarkoituksena on ehkäistä ja rajoittaa erityisesti pistämällä huumeita käyttävien veriteitse leviäviä tartuntoja. (26-28) Yhteiskunnassa pyritään toisaalta huumeiden käytön vähentämiseen ja ehkäisemiseen, toisaalta käytön haittojen vähentämiseen. Haittojen vähentäminen on osa Suomen kansallista huumausainestrategiaa. Terveysneuvontapisteet ovat osa huumeiden käytön haittojen vähentämisen strategiaa (27-28).

\section{TUTKIMUSKYSYMYKSET}

Tämän tutkimuksen tarkoituksena on kartoittaa pistettävien huumeiden käyttäjille tarkoitetun terveysneuvontapisteen asiakkaiden muutosvalmiutta ja siihen vaikuttavia tekijöitä. Tutkimme:

1. Millainen on neulanvaihtopisteen asiakkaiden muutosvalmiuden taso? Oletuksena on, että terveysneuvontapisteen asiakkaat ovat lähtökohtaisesti muutosmotivaatioltaan erilaisissa vaiheissa ja mukana on myös paljon esiharkintavaiheessa olevia päihteiden käyttäjiä. Toisaalta terveysneuvontapisteen asiakkaat saattavat olla huumeita suonensisäisesti säännöllisesti ja pitkäaikaisesti käyttäneitä ja väsyminen huumeiden käyttöön aineistossa saattaa korostua (22, 29-32).

2. Erotteleeko tutkimuksessa käytetty muutosvalmiuden mittari, DUDIT-E:n lyhennetty muutosvalmiusosio, aineistosta matalaa ja korkeaa muutosvalmiutta? Miten muutosvalmiudeltaan matala ja korkea ryhmä poikkeavat toisistaan taustamuuttujien sekä koetun hyvinvoinnin ja elämäntyytyväisyyden osalta? Mitkä tekijät ennustavat korkeaa muutosvalmiutta? Hypoteesi on, että huumeiden käytön subjektiivisesti koettu haitta ja tyytymättömyyden tai ahdingon tunne ovat yhteydessä korkeaan muutosvalmiuteen, kuten muutosvalmiuden teoriassa ja aikaisemmassa hoitokontekstin ulkopuolella tehdyssä empiirisessä tutkimuksessa.

\section{TUTKIMUKSEN TOTEUTUS}

\section{AINEISTON KERÄÄMINEN}

Aineisto kerättiin Kuopiossa huumeita suonensisäisesti käyttäville tarkoitetussa terveysneuvontapiste Portissa kesä-elokuussa 2013 ja lisäksi vielä syyskuussa 2013 yhden viikon ajan. Tutkimuksessa käytettiin strukturoitua lomaketta, joka noudattelee kansallisessa leipäjonotutkimuksessa (2010-2014) (33) käytettyä lomaketta. Lomake suunniteltiin nopeaksi ja helpoksi täyttää ja se on kokonaisuudessaan neljä sivua pitkä. Vastaajat täyttivät lomakkeen käyntinsä aikana tutkimusavustajan läsnä ollessa. Terveysneuvontapisteen työntekijät esittelivät kyselyä asiakkaille ja motivoivat heitä vastaamaan. Tutkimusavustaja auttoi tai ohjasi lomakkeiden täyttämisessä tarvittaessa. (26)

Jokaiselle Portin asiakkaalle pyrittiin tarjoamaan mahdollisuus vastata kyselyyn. Ennen lomakkeen täyttämisen ehdottamista huomioitiin tilannesidonnaisia tekijöitä, kuten asiakkaan päihtymystila ja mieliala. Aineiston keräysaikana terveysneuvontapisteessä asioi 208 eri asiakasta. Lomakkeita jaettiin yhteensä 112, joista 
100 palasi täytettyinä ja 8 keskeytettynä. Kyselyn vastausprosentti oli 48. Tutkimusavustajan arvion mukaan suurin osa vakioasiakkaista vastasi kyselyyn. Asiakkaiden käyntitiheyksiä ei kysytty eikä niitä ollut saatavilla. (26) Yksi lomake suljettiin pois aineistosta, koska siitä puuttui muutosvalmiutta koskevan osion vastaukset.

\section{Mittari}

Muutosvalmiutta tässä tutkimuksella mitattiin kuudella kysymyksellä. Kysymykset on poimittu DUDIT-E-mittarin huumeidenkäytön itsearvioinnin muutosvalmiutta mittaavasta osiosta, joka on nopeasti täytettävä, validi muutosvalmiuden mittari $(1,34)$. Sanamuotoja on hieman muutettu ja skaalana käytettiin 5-portaista Likert-asteikkoa (vastausvaihtoehdot täysin eri mieltä, osin eri mieltä, ei samaa eikä eri mieltä, osin samaa mieltä, täysin samaa mieltä). Väittämät ovat: Nautin huumeiden käytöstä, Olen ollut viimeisen vuoden aikana huolissani huumeiden käytöstäni, Olen väsynyt huumeiden käyttööni, Minusta on tärkeä tehdä muutos huumeiden käytössäni, Olen valmis tekemään töitä aikaansaadakseni muutoksen huumeiden käytössäni, Tarvitsen ammattiapua muuttaakseni huumeiden käyttöäni.

Muodostimme tätä tutkimusta varten elämäntyytyväisyyden summamuuttujan, joka kuvastaa elämäntyytyväisyyttä kokonaisuutena. Summamuuttujaan valittiin 14 taloudelliseen tilanteeseen, sosiaalisiin tekijöihin ja luottamukseen, fyysiseen ja henkiseen terveyteen sekä yleiseen elämäntyytyväisyyteen liittyvää kysymystä. Väittämät ovat: Kun ajattelet elämääsi viimeisen kuukauden aikana, oletko tuntenut itsesi tyytyväiseksi elämään/elintasoosi/terveyteesi/henkiseen terveyteesi; Kun ajattelet elämäsi viimeisen kuukauden aikana, oletko tuntenut itsesi masentuneeksi/yksinäiseksi; (vastausvaihtoehdot: jatkuvasti, melko usein, joskus, hyvin harvoin) sekä Tunnen itseni huono-osaiseksi; Pärjään elämässäni; Ihmisiin voi luottaa; Viranomaisiin voi luottaa; Tuloni riittävät menoibini; Pystyn huolehtimaan veloistani; Saan kaupungilta riittävästi tukea, apua ja palveluita ja Tulevaisundessa elämäni on parempaa (vastaus 5-portaisella Likert-asteikossa). Kysymyksiä on käytetty aikaisemmin kansallisessa leipäjonotutkimuksessa (33). Summamuuttujan sisäinen yhtenäisyys on hyvä (Cronbachin alpha=0,83).
Subjektiivista haittaa arvioitiin väittämällä Huumeiden käyttö aiheuttaa minulle ongelmia (vastaus 5-portaisella Likert-asteikolla). Yksittäisenä huumeiden käyttöön liittyvänä haittana kysyttiin huumeiden käyttöön liittyviä eri rikosoikeudellisia seuraamuksia viimeisen kahden vuoden aikana (ei rangaistuksia, sakko, yhdyskuntapalvelu, ehdollinen vankeus, ehdoton vankeus).

Palvelujen käytön osalta kysyttiin kunnan, Kelan ja eläkelaitoksen tarjoamien palvelujen ja tulonsiirtojen käyttöä sekä kunnan, seurakunnan ja Kelan tukemien palveluiden sekä mielenterveyspalveluiden ja päihdepalveluiden käyttöä (vastausvaihtoehdot: olen saanut, olen hakenut, mutta en ole saanut ja en ole hakenut). Lomakkeella kysyttiin yhteensä 13 eri etuuden ja 7 eri palvelun (mielenterveyspalvelut, päihdepalvelut, sosiaalitoimiston palvelut, terveyskeskuksen palvelut, Kelan tukema kuntoutus tai terapia, seurakunnan palvelut ja työvoimatoimiston palvelut) käyttöä tai hakemista.

Taustamuuttujista selvitettiin sukupuoli, kansalaisuus, ikä, huumeiden käytön aloitusikä, koulutus (perus- tai kansakoulun kesken, perustai kansakoulu, lukio tai ammattikoulu, opisto tai yliopisto), työtilanne (töissä pysyvästi, töissä määrä- tai osa-aikaisesti, työtön tai lomautettu, työkokeilussa, opiskelija, kotona, eläkeläinen), asumismuoto (omistusasunto, vuokra-asunto, kunnan vuokra-asunto, tukiasunto, asunnoton), ruokapankissa asioiminen (ei ole, joka viikko, keskimäärin kerran kuukaudessa, muutaman kerran vuodessa) ja uskonnollisen yhteisön toimintaan osallistuminen. Lisäksi kysyttiin kotitaloudessa asuvien aikuisten sekä lasten lukumäärää ja kuinka paljon kotitaloudelle jää käyttörahaa pakollisten menojen jälkeen. Kaikki tiedot perustuvat vastaajien omaan ilmoitukseen.

\section{TILASTOLLINEN ANALYYSI}

DUDIT-E:n muutosvalmiusosion kysymykset liittyvät kolmeen aihepiiriin: huumeiden käytön haittojen tunnistamiseen liittyvään yleiseen muutosvalmiuteen tai -toiveeseen, hoitovalmiuteen ja valmiuteen toimia muutoksen eteen. Väittämä "Nautin huumeiden käytöstä" edustaa muutosvalmiudelle vastakkaista tekijää, joka vähentää yleistä valmiutta (1). Tutkimme, löytyykö aineistosta mittarin oletusta noudattavaa faktoriraken- 
netta. Kaikki kuusi kysymystä latautuivat yhdelle faktorille, kun ehdoksi asetettiin yhden ominaisarvon ylittäminen. Yhden faktorin ratkaisu selitti $55,4 \%$ muuttujien vaihtelusta. Faktorointimenetelmänä oli generalized least squares. Muodostimme kuudesta muutosvalmiuskysymyksestä summamuuttujan, jota käytettiin analyyseissa. Summamuuttuja on keskiarvo vastauksista. Väittämä "nautin huumeiden käytöstä" on summamuuttujassa käännettynä. Summamuuttujan reliabiliteetti oli hyvä (Cronbachin alpha=0,83). Summamuuttuja sai arvoja yhdestä viiteen. Koska vastaukset annettiin Likert-asteikoilla, arvot 3,5:stä ylöspäin edustavat keskimääräisesti muutosvalmiusväittämien kanssa osittain tai täysin samaa mieltä olemista ja vastaavasti pisteet alle 2,5 väittämien kanssa eri mieltä olemista, mikä kuvastaa hyvin esiharkintavaiheessa olemista. DUDIT-E-mittarin pisterajoja ei käytetty tässä tutkimuksessa, sillä käytetty vastausasteikko on erilainen.

Vastaajat jaettiin kahteen ryhmään muutosvalmiuden perusteella (korkea vs. matala muutosvalmius). Näiden kahden ryhmän välisessä vertailussa käytettiin Pearsonin $\chi^{2}$-testiä. Parametrisiä menetelmiä käytettiin normaalijakautuneille muuttujille ja ei normaalisti jakautuneille muuttujille käytettiin non-parametrisiä menetelmiä (Mann-Whitney U). Muutosvalmiuteen vaikuttavia tekijöitä analysoitiin logistisen regressioanalyysin avulla, menetelmänä oli taaksepäin askeltava menetelmä. Tässä menetelmässä mallista poistetaan selittäjäksi valittuja muuttujia yksi kerrallaan perustuen niiden heikkoon selitysvoimaan. Aloitusmallin muuttujat valittiin sekä aikaisemman tutkimuksen että parametristen testien perusteella. Selittäjiksi valittiin ikä, sukupuoli, koulutus, työtilanne, uskonnollisen yhteisön toimintaan osallistuminen, huumeiden käytön subjektiiviset haitat, elämäntyytyväisyys ja myönteinen suhtautuminen ammattiapuun. Tilastollisen merkitsevyyden rajana pidettiin p-arvoa $<, 05$. Aineiston tilastollinen käsittely tehtiin SPSS 20-ohjelmalla.

\section{TULOKSET}

\section{OSALLISTUJAT}

Tutkimukseen osallistuneet terveysneuvontapisteen asiakkaat ovat melko nuoria. Suurin ikäryhmä olivat 26-35-vuotiaat. Enemmistö vastaajista oli miehiä. Vastaajien koulutustaso oli pääosin matala. Peruskoulun jälkeinen tutkinto oli alle puolella vastaajista ja $10 \%$ vastaajista ilmoitti, ettei ole käynyt perus- tai kansakoulua loppuun. Vastaajista suurin osa oli työelämän ulkopuolella vastaamishetkellä. Kokonaisuutena vastaajien taloudellinen toimeentulo oli heikkoa ja yli $80 \%$ vastaajista oli saanut toimeentulotukea viimeisen kahden kuukauden aikana. Huumeisiin liittyviä sakko- tai vankeustuomioita viimeisen kahden vuoden aikana oli noin puolella vastaajista.

Tutkimukseen osallistuneiden taustatiedot on esitetty taulukossa 1 .

\section{MUUTOSVALMIUDEN TASO JA MATALAN JA KORKEAN MUUTOSVALMIUDEN RYHMÄN VERTAILU}

Muutosvalmiuden mediaani aineistossa on 3,83 (asteikko 1-5). Esiharkintavaiheessa $(<2,5)$ on $9 \%$ vastaajista. Selvästi vähintään harkintavaiheessa $(>3,5)$ on $65 \%$ vastaajista.

Tutkimusta varten muodostettiin kaksi muutosvalmiusryhmää, matala $(\mathrm{n}=35, \mathrm{M}=2,67$, $\mathrm{sd}=, 64)$ ja korkea $(\mathrm{n}=64, \mathrm{M}=4,21, \mathrm{sd}=, 42)$, jakamalla muutosvalmiussummamuuttujan mukaan järjestetty aineisto käyttäen katkaisukohtana arvoa 3,5. Kuviossa 1 on esitetty muodostettujen muutosvalmiusryhmien vastausprofiilit. Korkean muutosvalmiuden ryhmä saa korkeampia pisteitä kaikissa muissa väittämissä, paitsi "nautin huumeiden käytöstä" ja matala päinvastoin.

Työtilanteen osalta eläkkeellä olevat sijoittuivat työssä käyviä ja opiskelijoita sekä työttömiä ja kotona olevia useammin matalan motivaation ryhmään, mutta muiden ryhmien välillä ei ollut tilastollisesti merkitseviä eroja. Uskonnollisen yhteisön toimintaan osallistuminen oli tavallisempaa korkean muutosvalmiuden ryhmässä. Muutosvalmiusryhmät eivät poikenneet toisistaan eri palveluiden käyttämisen osalta. Ryhmät eivät poikenneet toisistaan rikosoikeudellisten seuraamusten osalta.

$\mathrm{Ne}$, joiden muutosvalmius oli korkea, olivat tyytymättömämpiä elintasoonsa ja henkiseen terveyteensä, kokivat useammin masentuneisuu- 
Taulukko 1. Tutkimuksen osallistujat.

Vastaajien $(\mathrm{n}=99)$ esittely

$\%$ vastanneista $(\mathrm{n})$

Sukupuoli ${ }^{2}$

mies

$66(65)$

nainen

$32(32)$

Ikä3

$18-25$

$23(22)$

26-35

$59(57)$

yli 35

18 (17)

Kansalaisuus $^{5}$

suomalainen

99 (93)

Koulutus $^{1}$

oppivelvollisuus suorittamatta

peruskoulu tai kansakoulu

$46(45)$

vähintään toisen asteen tutkinto

45 (44)

Perhe

yksin asuva ${ }^{6}$

$54(50)$

lapsia $^{18}$

$20(16)$

Asunnoton $^{2}$

$10(10)$

Työtilanne $^{1}$

työ, työkokeilu tai opiskelija

työtön, lomautettu tai kotona

$65(64)$

eläkeläinen

$10(10)$

Tulonlähteet (voi olla useita, hk=henkilökohtainen, kt=kotitalous)

palkka $(\mathrm{hk})^{1}$

$11(11)$

ansiosidonnainen työttömyysturva $(\mathrm{kt})^{14}$

$12(10)$

Kelan etuus tai etuuksia $(\mathrm{kt})^{6-15}$

$91(71)$

toimeentulotuki $(\mathrm{kt})^{3}$

$84(81)$

leipäjono/ruokapankki viikoittain (hk) ${ }^{2}$

$7(7)$

leipäjono/ruokapankki harvemmin kuin viikoittain (hk)

$41(40)$

arvioi, että sukulaiset ja ystävät auttavat tarvittaessa (hk) ${ }^{3}$

$65(62)$

${ }^{\mathrm{n}}=$ puuttuva tieto

den tunteita sekä arvioivat useammin, että eivät pärjää elämässä eivätkä pysty huolehtimaan veloistaan. Korkean muutosvalmiuden ryhmässä elämäntyytyväisyys oli elämäntyytyväisyys-summamuuttujalla arvioituna matalampi kuin matalan muutosvalmiuden ryhmässä.

Korkea muutosvalmius liittyi huumeiden käytön subjektiivisesti arvioituun haitallisuuteen. Matalan muutosvalmiuden ryhmässä $37 \%$ ja korkean muutosvalmiuden ryhmässä $81 \%$ vastaajista arvioi, että huumeiden käyttö aiheuttaa heille ongelmia. Elämäntyytyväisyyteen liittyvien väittämien välillä oli vahva positiivinen korrelaatio. Sen sijaan elämäänsä tyytymättömät kokivat useammin, että huumeiden käyttö aiheuttaa heille ongelmia. Korkean muutosvalmiuden ryhmässä luottamus siihen, että ammattilaisilta voi saada oikeanlaista apua, oli suurempi kuin matalan muutosvalmiuden ryhmässä. Korkeamman muutosvalmiuden ryhmässä $77 \%$ vastaajista oli osin tai täysin samaa mieltä väittämän kanssa.

Tilastollisesti merkitsevät erot muutosvalmiusryhmien kokemuksissa on esitetty taulukossa 2. 


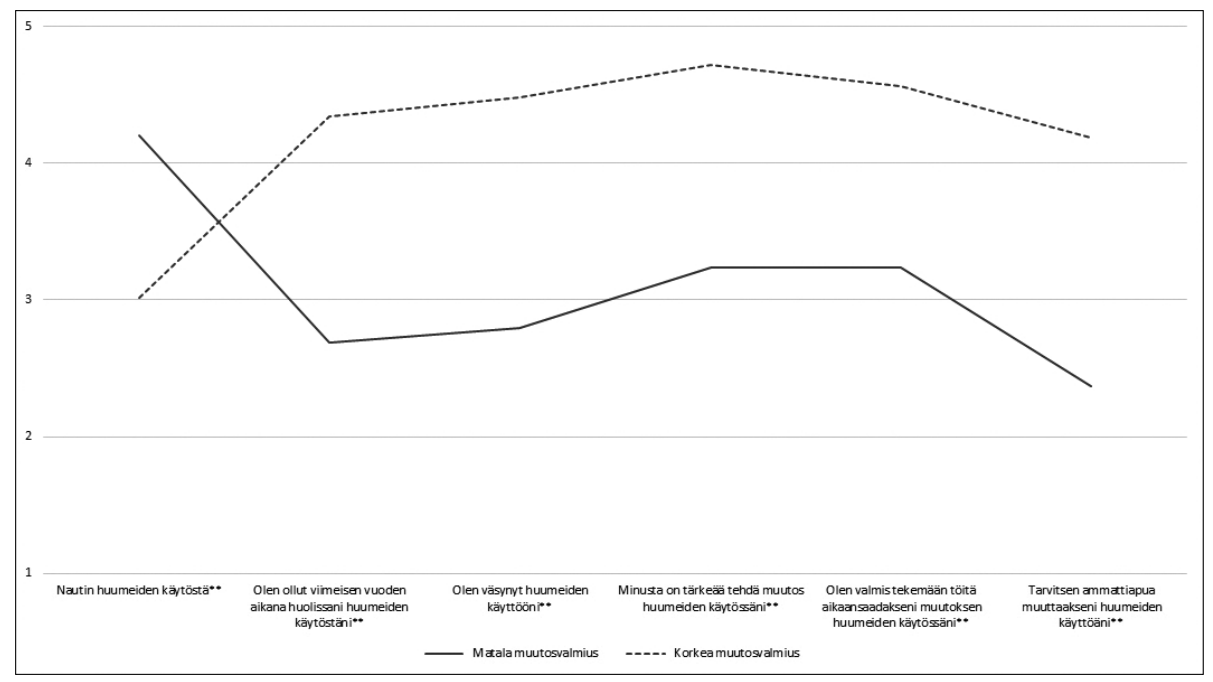

Kuvio 1. Muutosvalmiusryhmien muutosvalmiutta mittaavien kysymysten ryhmäkeskiarvot. Ryhmien väliset erot ovat tilastollisesti merkitseviä $\left(\mathrm{p}<.001^{* *}, \mathrm{p}<.05^{*}\right)$. (5=paljon/samaa mieltä... 1=vähän/eri mieltä)

Taulukko 2. Muutosvalmiusryhmien väliset tilastollisesti merkitsevät erot elämäntyytyväisyydessä ja asenteissa.

\begin{tabular}{|c|c|c|c|c|}
\hline & $\begin{array}{c}\text { Matala } \\
\text { muutosvalmius } \\
(\mathrm{n}=35)\end{array}$ & $\begin{array}{c}\text { Korkea } \\
\text { muutosvalmius } \\
(\mathrm{n}=64)\end{array}$ & Vastausasteikko & p-arvo \\
\hline Tyytyväisyys elintasoon & 2,29 & 1,89 & $1-4$ &, $035 *$ \\
\hline Tyytyväisyys henkiseen terveyteen & 2,85 & 2,48 & $1-4$ &, $034 *$ \\
\hline Masentuneisuuden tunne & 1,89 & 2,28 & $1-4$ &, $016 *$ \\
\hline Mahdollisuus huolehtia veloista ${ }^{1}$ & 3,76 & 3,07 & $1-5$ & ,019* \\
\hline Pärjäämisen kokemus ${ }^{2}$ & 3,91 & 3,36 & $1-5$ &, $017^{*}$ \\
\hline $\begin{array}{l}\text { Elämäntyytyväisyys } \\
\text { (summamuuttuja) }\end{array}$ & 3,15 & 2,82 & $1-4,56$ &, $010 *$ \\
\hline $\begin{array}{l}\text { Huumeiden käytön koettu } \\
\text { haitallisuus }\end{array}$ & 3,03 & 4,09 & $1-5$ &, $000 * *$ \\
\hline $\begin{array}{l}\text { Myönteinen suhtautuminen } \\
\text { ammattiapuun }\end{array}$ & 3,20 & 4,16 & $1-5$ & $001 * *$ \\
\hline
\end{tabular}

Mann-Whitneyn $\mathrm{U} p<, 001^{* * *}, \mathrm{p}<, 05^{*}$

1=samaa mieltä väittämän "Pystyn huolehtimaan veloistani" kanssa; $2=$ Samaa mieltä väittämän Pärjään elämässäni” kanssa; 3 = Samaa mieltä väittämän "Voin saada oikeanlaista apua ammattilaisilta" kanssa. Tyytyväisyys elintasoon, Tyytyväisyys henkiseen terveyteen, Masentuneisuuden tunne, Mahdollisuus huolehtia veloista ja Pärjäämisen kokeminen ovat mukana Elämäntyytyväisyyden summamuuttujassa. 
Taulukko 3. Muutosvalmiutta ennustavat tekijät (logistinen regressioanalyysi, referenssikategoriana korkea muutosvalmius).

\begin{tabular}{lccc} 
& OR & $\begin{array}{c}95 \% \\
\text { luottamusväli }\end{array}$ & p-arvo \\
\hline Huumeiden käytön koettu haitallisuus & 2,74 & $1,58-4,75$ & $<, 001^{* *}$ \\
Myönteinen suhtautuminen ammattiapuun & 2,12 & $1,35-3,32$ &, $001^{* *}$ \\
Työssä käyminen, työkokeilu tai opiskelu & 9,87 & $1,20-81,16$ &, $033^{*}$ \\
\hline $\mathrm{p}<, 001^{* *}, \mathrm{p}<, 05^{*}$ & & &
\end{tabular}

\section{MUUTOSVALMIUTEEN YHTEYDESSÄ OLEVAT TEKIJÄT}

Muutosvalmiutta selittäviä tekijöitä logistisessa regressiomallissa (taulukko 3) olivat subjektiivinen haitan kokemus, myönteinen suhtautuminen ammattiapuun sekä työtilanne. Mallin sopivuus on melko hyvä (Cox \& Snell R²=,319; Nagelkerke $\mathrm{R}^{2}=, 438$ ) ja malli luokitteli oikein $77 \%$ kaikista ja $87 \%$ korkean muutosvalmiuden ryhmään kuuluvista.

Huumeiden käytön kokeminen haitalliseksi ja myönteinen suhtautuminen ammattiapuun ennustavat korkeaa muutosvalmiutta. Myös työssä käyminen, työkokeilu tai opiskeleminen lisäsivät todennäköisyyttä sille, että kuuluu korkean muutosvalmiuden ryhmään, mutta tulos ei ole yhtä luotettava.

\section{POHDINTA}

\section{TULOSTEN TARKASTELU}

Terveysneuvontapisteiden palveluja käyttävien huumeita suonensisäisesti käyttävien muutosvalmius on korkealla tasolla. Esiharkintavaiheessa tässä aineistossa oli vain $9 \%$ vastaajista, selvästi vähintään harkintavaiheessa $65 \%$ vastaajista. Valtaosa vastaajista toivoo ja harkitsee muutosta huumeiden käyttöön liittyen ja toivoo saavansa muutokseen myös ammattiapua. Korkea muutosvalmius aineistossa kytkeytyy vastaajien hyvinvoinnin puutteisiin ja matalaan elämäntyytyväisyyteen. Elämäänsä tyytymättömimmät olivat myös niitä, joiden muutosvalmius oli korkeimmalla tasolla. Tämä kertoo siitä, että tutkimusaineistossa on suuri joukko, jotka ovat erityisen väsyneitä huumeiden käyttöönsä ja elämäntilanteeseensa.
Korkea muutosvalmius tässä aineistossa oli yhteydessä subjektiiviseen haitan kokemiseen, ammattiavun hyödylliseksi arvioimiseen ja heikkoon arvioon subjektiivisesta hyvinvoinnista elämäntyytyväisyyden, pärjäämisen, henkisen hyvinvoinnin ja taloudellisen tilanteen osalta. Henkinen ahdinko, joka voi ilmetä tunteena henkisen terveyden kärsimisestä tai masentuneisuutena, on yksi entuudestaan tunnettu korkeampaan muutosvalmiuteen kytkeytyvä tekijä. (2, 9-11, 15-16) Mielenterveyden kärsimisen oireet voivat olla huumeiden käyttöön liittyvä haitta, ahdistus voi liittyä huumeiden käytön haittojen tunnistamiseen ja myös toisin päin, ahdingon tunne voi saada haluamaan muutosta (2). Taloudelliset huolet olivat yhteydessä korkeampaan muutosvalmiuteen. Vastaajat olivat kokonaisuudessaan taloudellisesti heikossa asemassa ja lisäksi huumeiden käytön rahoittamiseen liittyvät tekijät ja niihin liittyvät vaikeudet saattavat olla välittävä tekijä taloudellisen hyvinvoinnin ja muutosvalmiuden välisessä yhteydessä.

Aikaisemmissa tutkimuksissa on huomattu, että päihdeongelman haittojen tunnistaminen (9-10) ennustaa muutosvalmiutta paremmin kuin sosiodemografiset tekijät, kuten ikä tai sukupuoli. Tässä tutkimuksessa sosiodemografisista tekijöistä vain työtilanne oli yhteydessä muutosvalmiuteen. Sekä työssä käyminen ja opiskelu että työttömyys tai lomautettuna oleminen olivat yhteydessä korkeaan muutosvalmiuteen, kun taas eläkkeellä olevilla muutosvalmius oli matalampaa. Eläkeläiset olivat omasta huumeiden käytöstään vähemmän huolissaan kuin muut vastaajat. Monet heistä olivat saaneet viime aikoina kuntoutusta tai terapiaa ja on mahdollista, että tätä vastaajaryhmää leimasi rauhallisempi 
suvantovaihe joko elämässä tai huumeiden käytössä. Opiskelijoilla ja työssä käyvillä työ ja opiskelu voivat olla resursseja, joista halutaan pitää kiinni tai jotka lisäävät muutosvalmiutta lisäämällä pystyvyysuskoa myös muutoksen suhteen. Työttömillä muutosvalmiuden lisääntyminen taas saattaa liittyä elämäntilanteen epätyydyttävyyteen. Yleisesti on syytä myös huomata, että matalammat muutosvalmiuden pisteet voivat liittyä myös vähäisempään huumeiden käyttöön.

Tulokset kertovat osaltaan siitä, että halukkuutta muutokseen on kaiken tyyppisillä terveysneuvontapisteen asiakkailla eikä ulkoisilla tekijöillä juurikaan voitu ennustaa muutosvalmiutta. Esimerkiksi asunnottomien muutosvalmius ei poikennut muiden vastaajien muutosvalmiudesta. Verrattuna hoitopopulaatioihin vastaajajoukko saattaa olla homogeenisempää ja taustamuuttujien vaikutus jää siksi vähäisemmäksi. Vastaajien mahdollinen valikoituminen on entuudestaan lisännyt vastaajien yhtenäisyyttä.

Uskonnollisen yhteisön toimintaan osallistuminen oli yhteydessä korkeaan muutosvalmiuteen. Uskonnolliset yhteisöt ovat merkittäviä toiminnan ja kuntoutuksen järjestäjiä päihdeongelmaisille ja niiden toiminta saattaa tavoittaa myös sellaisia huumeiden käyttäjiä, jotka eivät ole muun psykososiaalisen tuen piirissä. Vastaajat eivät välttämättä pidä uskonnollisen yhteisön järjestämää toimintaa tai omaa osallistumistaan yhteisön toimintaan uskonnollisena (26). Uskonnollisen yhteisön toimintaan osallistuminen saattaa olla yhteydessä muutosvalmiuteen hengellisyyden kautta, mutta tämän tutkimuksen perusteella ei voida sanoa, mikä merkitys hengellisyydellä oli vastaajille. Tulos voi liittyä myös siihen, että huumeiden käyttöön muutosta kaipaavat saattavat hakeutua monenlaisen psykososiaalisen avun ja tuen pariin. Muutosvalmiuden ja psykososiaalisen tuen yhteys saattaa olla kaksisuuntainen: muutosvalmius selittää palvelujen piiriin hakeutumista ja palvelujen piirissä oleminen voi tukea muutosvalmiuden kehittymistä.

Selvimmin korkeaa muutosvalmiutta ennustivat huumeiden käytön kokeminen haitalliseksi ja myönteinen suhtautuminen ammattiapuun. Arvio huumeiden käytön itselle aiheuttamista ongelmista on keskeinen muutosvalmiuden osatekijä kognitiivisissa muutosmotivaatiomalleissa
$(1,5,7-8)$ ja tämän tutkimuksen perusteella malli pätee myös terveysneuvontapisteiden asiakkaiden muutosvalmiuden kuvaamiseen. Tulos vastaa aikaisemman tutkimuksen perusteella asetettua hypoteesia. Luottamus siihen, että ammattilaisilta voi saada apua, on yksi hoito- ja muutosvalmiutta nostava tekijä (18), mutta vaikutus on samalla todennäköisesti myös toisen suuntainen. Muutosvalmiuden viriäminen saa harkitsemaan ammattiavun käyttämistä ja mahdollisesti myös lisäämään siihen tukeutumista ja luottamista.

Henkinen ahdinko, jota tässä tutkimuksessa arvioitiin itseilmoitettuna masentuneisuuden tunteina ja heikentyneenä elämäntyytyväisyytenä, saattaa kytkeytyä korkeaan muutosvalmiuteen. Henkinen ahdinko ei kuitenkaan selittänyt muutosvalmiutta tässä tutkimuksessa. Tyytymättömyys elämään ja sen eri osa-alueisiin ei ollut yhtä selvässä yhteydessä muutosvalmiuteen. Elämäntyytyväisyyskysymyksiä tässä tutkimuksessa ei ollut kytketty huumeiden käyttöön vaan elämään yleensä. Hyvinvointierot ryhmässä eivät myöskään olleet suuria. Osa vastaajista hakee ratkaisua epätyydyttävään elämäntilanteeseensa pyrkimällä eroon huumeista, kun taas osalle vastaajista tyytymättömyyden taustalla olevat vaikeudet kuvautuvat muutoksen ulkoisina tai sisäisinä hidasteina ja esteinä.

\section{TUTKIMUKSEN LUOTETTAVUUS}

Tulosten tulkinnassa on otettava huomioon, että tutkimuksen osallistujajoukko oli mahdollisesti jossain määrin valikoitunutta. Muutamissa parametrisissa mittauksissa osajoukot jäivät pieniksi, mikä heikentää tulosten yleistettävyyttä. Portin käyttäjistä vakioasiakkaat vastasivat Portin henkilökunnan ja tutkimusavustajan arvion mukaan useammin kuin ensimmäistä kertaa käyvät asiakkaat (26). Niinpä tulokset kertovat ehkä erityisesti huumeiden aktiivisten ja pitkäaikaisten käyttäjien kokemuksista tai ainakin terveysneuvontapisteen aktiivikäyttäjien kokemuksista.

Tutkimuksessa muutosvalmiutta mitattiin tätä tutkimusta varten laaditulla kuuden kysymyksen mittarilla. Koska muutosvalmiudesta kysyttiin suoraan, voi mittari olla altis sosiaalisten odotusten mukaiselle vastaamiselle (1). Kielteiset vastaukset väittämiin kuvastavat hyvin esiharkintavaihetta. Sen sijaan suuri yksimielisyys 
väittämien kanssa voi olla mahdollista harkinta-, valmistelu- tai toimintavaiheessa. Pisteet myös oletuksen mukaan laskevat, jos huumeiden käyttöön on jo tehty muutoksia. Tässä tutkimuksessa ei kysytty, minkä verran vastaajat käyttävät parhaillaan huumeita.

Kuuden kysymyksen mittarilla saatiin muutosmotivaation ja muutosvalmiuden teoriataustan ja aikaisemman tutkimuksen kanssa yhteensopivia tuloksia, mikä sinänsä kertoo siitä, että mittarin validiteetti on lupaava. Kokonaisen DUDIT-E-itsearviointiskaalan käyttö olisi mahdollistanut tässä saatujen tulosten vertaamisen muuhun tutkimukseen ja käytössä oleviin raja-arvoihin. Tutkimuslomake haluttiin pitää kuitenkin lyhyenä ja helposti täytettävänä. Terveysneuvontapisteiden käyttäjien anonymiteettiä kunnioitettiin, eikä tätä tutkimusta varten asiakkaista kerätty varsinaisia henkilötietoja.

\section{JOHTOPÄÄTÖKSET}

Tutkimuksen perusteella huumeita suonensisäisesti käyttävien terveysneuvontapisteiden vakiokäyttäjien parissa väsyneisyys huumeiden käyttämiseen ja toive muuttaa huumeiden käyttöä on hyvin tavallista. Terveysneuvontapisteet tarjoavat päihdehoitoon liittyvää neuvontaa, mikä tämän tutkimuksen perusteella vastaa useiden terveysneuvontapisteen käyttäjien tarpeita. Näiden henkilöiden tunnistamista vaikeuttaa kuitenkin se, että ulkoisten tekijöiden perusteella on vaikeaa arvioida muutosvalmiutta. Lyhyt subjektiivisen muutosvalmiuden kartoituksen menetelmä voi auttaa seulomaan ne, jotka kaipaavat muutosta ja mahdollisesti apua muutokseen juuri tietyllä hetkellä. DUDIT-E muutosvalmius-osion tyylinen lyhyt mittari vaikuttaa pätevältä muutosvalmiuden nopean kartoituksen menetelmältä.

Tässä tutkimuksessa huumeiden käytön koettu haitallisuus ja elämään liittyvä tyytymättömyyden ja ahdingon kokemus olivat yhteydessä korkeaan muutosvalmiuteen. Muutosmotivaation kognitiiviset mallit soveltuvat hyvin muutosvalmiuden kuvaamiseen. Huumeettomuuteen vetäviä tekijöitä ja muutoksen toteuttamisen voimavaratekijöitä ja esteitä ei tässä tutkimuksessa kartoitettu, vaikka niiden rooli etenkin muutosprosessin edetessä on tärkeä. Terveysneuvontapiste Portin asiakkaiden itseilmaistu muu- tosvalmius (ja erilaisten palveluiden käyttö) on korkealla tasolla, mutta heidän kykynsä, voimavaransa, edellytyksensä ja välineensä muutoksen toteuttamiseen eivät välttämättä ole vastaavalla tasolla. Paitsi että huumeiden käyttäjien hyvinvoinnin tukeminen on itseisarvoisesti tärkeää, myös muutosmotivaation näkökulmasta tyydyttävän elämän hankkiminen ja elämäntyytyväisyyden ylläpitäminen ovat huumeiden käyttöönsä muutosta suunnittelevien ja heitä kohtaavien palvelujärjestelmien jatkuvana haasteena. Tulostemme perusteella tarvitaan lisää tietoa siitä, miten muutosvalmiutta voisi parhaiten hyödyntää hoitoa ja hoitoon sitoutumista edistävänä tekijänä. Mikäli potilaan muutosvalmius ja muutosta edistävät tekijät ja niiden merkitys pystyttäisiin tunnistamaan paremmin, Portin tavoin toimivat matalan kynnyksen pisteet voisivat kohdentaa tarkemmin yksilöityä neuvontaa ja ohjausta huumeita suonensisäisesti käyttäville. Tämä voisi parantaa huumeita suonensisäisesti käyttävien henkilöiden kokemusta ymmärretyksi tulemisesta ja sitä kautta lisätä heidän sitoutumistaan päihdehoitoon.

\section{KIRJOITTAJIEN KONTRIBUUTIOT}

$\mathrm{PH}$ ja AMP osallistuivat tutkimussuunnitelman tekemiseen, aineiston analysointiin ja tutkimuksen raportointiin. $\mathrm{KH}$ osallistui tutkimuksen arviointimenetelmien suunnitteluun, tutkimussuunnitelman tekemiseen, aktiivisesti tämän käsikirjoituksen suunnitteluun ja ohjasi käsikirjoituksessa kuvatun tutkimuksen raportoinnin suunnittelua ja koostamista. PS osallistui tutkimuksen suunnitteluun, järjesti aineiston keräämisen ja ohjasi aineiston keruuta sekä oli mukana raportoinnin suunnittelussa. JS on tutkimuksen johtaja ja osallistui tutkimuksen suunnitteluun, ohjasi aineiston keräämisen ja oli mukana tutkimusraportoinnin suunnittelussa.

\section{KIITOKSET}

Kirjoittajat kiittävät sairaanhoitaja Annina Kaarijokea ja sosiologian maisteriopiskelija Kristiina Laipiota tutkimukseen osallistuneiden asiakkaiden empaattisesta motivoimisesta ja tarvittaessa heidän avustamisestaan, mikä kaikki mahdollisti tutkimuksen onnistumisen. 
The aim of the research is to examine the readiness for change and factors associated with it in intravenous drug users. Readiness for change means self-described willingness and readiness to change drug use, act towards the change and accepting professional help. The material ( $\mathrm{N}=99)$ was collected at the health advice centre Portti in Kuopio, which is meant to drug users who use drugs intravenously. The readiness for change is evaluated with an indicator which was specifically created for this research. The indicator is based on the self-evaluation section of DUDIT-E-indicator, which measures the seriousness of drug use and motivation for change. We also examined the satisfaction with life of the respondents. We created for this research the sum of the variable of the satisfaction with life. We compared groups with higher and lower readiness for change. The readi- ness for change was at a high level among visitors of Portti. The majority of respondents had a desire to change their drug use patterns. The factors that predicted readiness for change were self-described harmfulness of drug use, positive attitude towards professional help and working, practical training or studying. Respondents who had higher readiness for change also used more religious communities' services. If it was possible to recognize the readiness for change and factors that help the progress of change and the significance of them, the low threshold services like Portti could target better individualized counseling and guidance to persons who use drugs intravenously.

Keywords: readiness for change, DUDIT-E, Health advice centre Portti, intravenous drug use, satisfaction with life

\section{LÄHTEET}

(1) Berman AH, Palmstierna T, Källmén $H$, ym. The self-report Drug Use Disorders Identification Test-Extended (DUDIT-E): Reliability, validity, and motivational index. J Subst Abuse Treat 2007;32: 357-369.

(2) Miller W. Motivaation ja muutoksen käsitteellistäminen. Kirjassa: KoskiJännes A, Riittinen L, Saarnio P. (toim.) Kohti muutosta. Motivointimenetelmiä päihde- ja käyttäytymisongelmiin. Helsinki: Kustannusosakeyhtiö Tammi; 2008, 16-40.

(3) Norcross J, Krebs P, Prochaska J. Stages of Change. J Clin Psychol 2011;67: 143-154.

(4) Bell DC, Montoya ID, Richard AJ, ym. The Motivation for Drug Abuse Treatment: Testing Cognitive and 12-Step Theories. Am J Drug Alcohol Abuse 1998;24: 551-571.

(5) DiClemente CC, Schlundt D, Gemmell L. Readiness and Stages of Change in Addiction Treatment. Am J Addict 2004;13: 103-119.

(6) Hiller M, Narevic E, Webster M, ym. Problem Severity and Motivation for Treatment in Incarcerated Substance Abusers. Subst Use Misuse 2009;44: 28-41.

(7) Simpson D, Joe G. Motivation as a predictor of early dropout from drug abuse treatment. Psychotherapy 1993;30: 357-368.

(8) De Leon G, Melnick G, Kressel D. Motivation and Readiness for Therapeutic Community Treatment among Cocaine and Other Drug

Abusers. Am J Drug Alcohol Abuse 1997;23: 169-189.

(9) Rapp RC, Xu J, Carr CA, ym. Understanding treatment readiness in recently assessed, pre-treatment substance abusers. Subst Abus 2007;28: 11-23.

(10) Zule WA, Lam WKK, Wechsberg WM Treatment Readiness Among Out-of-Treatment African-American Crack Users. J Psychoactive Drugs 2003;35: 503-510.

(11) Nwakeze P, Magura S, Rosenblum A. Drug problem recognition, desire for help and treatment readiness in a soup kitchen population. Subst Use Misuse 2002;37: 291-312.

(12) Upshur C, Weinreb L, Cheng D, ym. Does Experiencing Homelessness Affect Women's Motivation to Change Alcohol or Drug Use? Am J Addict 2014;23: 76-83.

(13) Collins J, Slesnick N. Factors Associated With Motivation to Change HIV Risk and Substance Use Behaviors Among Homeless Youth. J Soc Work Pract Addict 2011;11: 163-180.

(14) Lobmaier P, Berman A, Gossop M, ym. Substance use and problem awareness among drug-involved prisoners in Norway. J Subst Use 2013;18: 211-220.

(15) Ryan R, Plant R, O’Malley S. Initial motivations for alcohol treatment: relations with patient characteristics, treatment involvement, and dropout. Addict Behav 1995;20: 279-297. 
(16) Nochajski T, Stasiewicz PR, Patterson DA. Depression, Readiness for Change, and Treatment Among Court-Mandated DUI Offenders. J Dual Diagn 2013;9: 139-148.

(17) Schwartz R, Kelly S, O’Grady K, ym. Antecedent and correlates of methadone treatment entry: A comparison of out-oftreatment and in-treatment cohorts. Drug Alcohol Depend 2011;115: 23-29.

(18) DiClemente CC, Doyle SR, Donovan D. Predicting Treatment Seekers' Readiness to Change their Drinking Behavior in the COMBINE Study. Alcohol Clin Exp Res 2009;33: 879-892.

(19) Varjonen V, Tanhua H, Forsell M. Huumetilanne Suomessa 2013. Terveyden ja hyvinvoinnin laitos. Raportti 5/2014.

(20) Winick C. Maturing Out of Narcotic Addiction. Bull Narc 1962;14: 1-7.

(21) Henderson L, Vlahov D, Celentano D, ym. Readiness for Cessation of Drug Use Among Recent Attenders and Nonattenders of a Needle Exchange Program. J Acquir Immune Defic Syndr 2003;32: 229-237.

(22) Laudet A, Becker J, White W. Don't Wanna Go Through That Madness No More: Quality of Life Satisfaction as Predictor of Sustained Remission from Illicit Drug Misuse. Subst Use Misuse 2009;44: 227-252.

(23) De Maeyer J, Vanderplasschen W, Broekaert E. Quality of life among opiate-dependent individuals: A review of the literature. Int J Drug Policy 2010;21: 364-380.

(24) Fischer J, Clavarino A, Kemp R, ym. Quality of life of people who inject drugs: characteristics and comparisons with other population samples. Qual Life Res 2013;22: 2113-2121.

(25) Diener, E., Emmons, R., Larsen, R. \& Griffin, S. The Satisfaction With Life Scale. J Pers Assess 1985;49: 71-75.

(26) Laipio K, Saari J, Honkalampi K, ym. Terveysneuvontapiste Portin asiakkaat Kuopiossa. Suonensisäisten huumeiden käyttäjien hyvinvointi sekä palveluiden ja tulonsiirtojen käyttö. Kuopio: Kuopion kaupunki; 2014.

(27) Sosiaali- ja terveysalan tutkimus- ja kehittämiskeskus. Ehkäisevän päihdetyön laatukriteerit. Stakesin työpapereita 3/2006.

(28) Warsell L, Vertio H. Päihdehaittojen ehkäisystrategiat ja ehkäisevä päihdetyö. Kirjassa Salaspuro M, Kiianmaa K, Seppä K. (toim.) Päihdelääketiede. Jyväskylä: Gummerus Kirjapaino Oy; 2003, 47-56.

(29) Kuoppasalmi K, Heinälä P, Lönnqvist J. Päihdehäiriöt. Kirjassa: Lönnqvist J, Henriksson M, Marttunen M, Partonen T. (toim.) Psykiatria. Keuruu: Otavan Kirjapaino Oy; 2013, 405-470.
(30) Van der Poel A, Barendregt C, van de Mheen D. Drug Users' Participation in Addiction Care: Different Groups Do Different Things. J Psychoactive Drugs 2006;38: 123-132.

(31) Koivula U-M., Saari, M, Saari J, ym. "Ilman Nerviä en olisi hengissä” Kyselytutkimus A-klinikkasäätiön Pirkanmaan palvelualueen terveys- ja sosiaalineuvontapiste Nervin asiakkaiden hyvinvoinnista ja palveluiden käytöstä. Tampereen kaupungin julkaisuja. Selvitykset ja kehittämisraportit 4/2014.

(32) Bluthenthal R, Gogineni A, Longshore D, ym. Factors associated with readiness to change drug use among needle-exchange users. Drug Alcohol Depend 2001;62: 225-230.

(33) Ohisalo M, Saari J. Kuka seisoo leipäjonossa? Ruoka-apu 2010-luvun Suomessa. Kunnallisalan kehittämissäätiön Tutkimusjulkaisu-sarjan julkaisu nro 83 . Sastamala: Vammalan kirjapaino Oy; 2014.

(34) Matuszka B, Bácskai E, Berman AH, ym. Psychometric Characteristics of the Drug Use Disorders Identification Test (DUDIT) and the Drug Use Disorders Identification Test-Extended (DUDIT-E) Among Young Drug Users in Hungary. Int J Behav Med 2014;21: 547-555.

\section{PÄlvi Havukainen \\ PsM, psykologi \\ Ylä-Savon SOTE ky, Koulutiimi, \\ Iisalmi}

Anna-Mari Pasanen

PsM, psykologi

Siun sote, Lastenpsykiatrinen poliklinikka, Joensun

\section{KiRsi HONKALAMPI}

Ma. Professori

Itä-Suomen yliopisto

Kasvastustieteen ja psykologian osasto

Joensun

\section{Pirjo SAARINen \\ LT, dosentti}

Lääkintäneuvos, osastonylilääkäri

Kuopion yliopistollinen sairaala

Mielenterveysjohtaja

Kuopion kaupunki

JUHO SAARI

VTT, MA (Econ.)

Professori, johtaja

Kuopion Hyvinvointitutkimuskeskus (KWRC)

Itä-Suomen yliopisto

Yhteiskuntatieteiden laitos, Kuopio 